\title{
АНТИАГРЕГАНТИ ПРИ ІШЕМІЧНОМУ ІНСУЛЬТІ 3 ПОГЛЯДУ СОЦІАЛЬНОї ФАРМАЦІї
}

\author{
(с). Р. Левицька, Б. П. Громовик
}

\author{
Львівський національний медичний університет імені Данила Галицького \\ levytska.oksana@gmail.com, hromovyk@gmail.com
}

\begin{abstract}
Мета роботи. Ситуативний аналіз номенклатури зареєстрованих в Україні антиагрегантів (АА), їх продуктової та цінової кон'юнктури, а також економічної доступності.

Матеріали і методи. Дані з Державного реєстру лікарських засобів (ЛЗ) України, інсрормація з сайту «Аптека online.ua». Розраховували коесріцієнт ліквідності ціни (Kliq), вартість встановленої добової дози (DDD), аналізували роздрібну вартість ЛЗ клопідогрелю у рамках програми «Доступні ліки».

Результати й обговорення. Ситуативний аналіз продуктової кон'юнктури АА дозволив установити 32 зареєстровані торгові назви (ТН) моно- та 2 ТН комбінованих Лз клопідогрелю; 22 ТН моно- та 4 комбінованих Лз АСК; по одному ЛЗ тиклопідину та трифрлузалу. Максимальна вартість DDD (понад 20 грн) притаманна для 2-х ТН клопідогрелю та одну TH трифрлузалу. Мінімальна вартість DDD (менш ніж 2 грн) характерна для майже 90 \% ТН АCK, а також для 5-ти ТН клопідогрелю. Для 4 ТН клопідогрелю, 10 TH АСК, ТН тиклопідину та трифрлузалу Kliq був меншим 0,15; для 20 ЛЗ клопідогрелю та 4 ЛЗ АСК - знаходився у межах 0,15 - 0,49, а для 5 ЛЗ АСК був вищим 0,5. 3'ясовано, що реєстр ЛЗ, вартість яких підлягає відшкодуванню (в рамках урядової програми «Доступні ліки»), включає 23 ТН клопідогрелю. Відсоток доплати за упаковку ЛЗ коливається у межах 0 - 49,5\%.

Висновки. Встановлено, що продуктова кон'юнктура АА на момент дослідження сумарно налічувала 62 ТН ЛЗ. Виявлено, що серед АА найбільш економічно доступними є ЛЗ АСК, оскільки для більш ніж половини 3 них вартість DDD є меншою 1 грн. Низька економічна доступність характерна для 2-х ТН клопідогрелю (плавікс та коплавікс), а також ТН трифлузалу (дісгрен). Аналіз значень коефіцієнта ліквідності ціни засвідчив, що на момент дослідження ціни на більшість АА були коректними відносно споживачів, а висока цінова конкуренція притаманна 5 ЛЗ АСК. У межах урядової програми «Доступні ліки» одну ТН клопідогрелю пацієнти можуть отримати безкоштовно, для 19 ТН відшкодовується 61,9 - 98,9 \% їх вартості, а за 3 ТН споживачі повинні доплатити близько половини їх вартості.
\end{abstract}

Ключові слова: ішемічний інсульт; антиагреганти; соціальна фрармація.

Вступ. Антиагрегантна терапія є одним 3 важливих методів реперфузії (відновлення кровотоку в ішемізованій ділянці мозку) в гострому періоді ішемічного інсульту (iі). Іїі застосовують також і з метою вторинної профрілактики. Особливості застосування антиагрегантів (AА) при іі висвітлені нами в монографії «Ішемічний інсульт: клініко-орармацевтичні аспекти» [1]. Препаратом вибору як в гострому періоді II, так і при вторинній профрілактиці є ацетилсаліцилова кислота (АСК). 3 метою вторинної профрілактики рекомендують використовувати також клопідогрель, трифрлузал [2], дипіридамол з модифрікованим вивільненням [3], тиклопідин [4] тощо.

31 квітня 2017 р. в Україні діє урядова програма «Доступні ліки», у рамках якої пацієнти за рецептом лікаря можуть отримати безкоштовно або з доплатою ЛЗ для лікування серцево-судинних захворювань, цукрового діабету II типу та бронхіальної астми. Перелік міжнародних непатентованих назв лікарських засобів (МНН ЛЗ), які включені до програми, затверджено Постановою Кабінету Міністрів України
(КМУ) від 09.11.2016 р. № 863 [5] із змінами, внесеними Постановами КМУ від 17.03.2017 р. № 152 [6] та від 27.12.2017 р. № 1080 [7]. Наказом МО3 України від 22.01.2018 р. № 111 затверджено реєстр Л3, вартість яких підлягає відшкодуванню, який налічує 239 препаратів [8]. 3 групи АА у цей реєстр включено клопідогрель. Вказане вище зумовлює актуальність досліджень АА з позицій соціальної фрармації, хоча АА вже були об'єктами низки наукових досліджень [911].

Мета роботи - ситуативний аналіз номенклатури зареєстрованих в Україні АА, їх продуктової та цінової кон'юнктури, а також економічної доступності.

Матеріали і методи. Номенклатуру та кількість зареєстрованих в Україні АА аналізували за даними Державного реєстру ЛЗ України [12], продуктову та цінову кон'юнктуру їх ринку - за інфрормацією, розміщеною на сайті «Аптека online.ua» в рубриці «Ціни на ліки» шляхом розрахунку та порівняння коефріцієнта ліквідності ціни (Kliq) [13], економічну доступність на підставі таких показників, як вартість встановленої

ISSN 2312-0967. Pharmaceutical review. 2018. № 3 
добової дози (defined daily dose, DDD) за мінімальною закупівельною ціною (МЗЦ) та роздрібна вартість ЛЗ клопідогрелю у рамках програми «Доступні ліки». Період дослідження - липень 2018 р.

Результати й обговорення. На момент дослідження в Україні було зареєстровано 32 торгові назви (ТН) моно- та 2 ТН комбінованих Л3 клопідогрелю (сумарно 54,8 \% аналізованої номенклатури); 22 ТН моно- та 4 комбінованих ЛЗ АСК (41,9% номен- клатури); по одній лз тиклопідину та трифрлузалу (по 1,6 \% номенклатури). При цьому 2/3 цих Л3 іноземного виробництва. Оскільки в аналізованих джерелах інфрормація про ЛЗ дипіридамолу з модисрікованим вивільненням була відсутня, то його не включено в аналіз.

Результати дослідження вартості DDD лз за МЗЦ у розрізі окремих МНH та фрорм випуску ЛЗ представлено в таблиці 1.

Таблиця 1. Результати аналізу вартості DDD антиагрегатів за мінімальною закупівельною ціною

\begin{tabular}{|c|c|c|c|c|c|}
\hline ТН ЛЗ & $\begin{array}{c}\text { K-сть } \\
\text { пропоз. }\end{array}$ & $\begin{array}{l}\text { МЗЦ, грн/ } \\
\text { вартість } \\
\text { DDD, грн }\end{array}$ & ТН ЛЗ & $\begin{array}{c}\text { К-сть } \\
\text { пропоз. }\end{array}$ & $\begin{array}{l}\text { МЗЦ, грн/ } \\
\text { вартість } \\
\text { DDD, грн }\end{array}$ \\
\hline 1 & 2 & 3 & 4 & 5 & 6 \\
\hline \multicolumn{3}{|c|}{$\begin{array}{c}\text { Клопідогрель } 75 \text { мг } \\
\left(\mathrm{DDD}^{*}-75 \mathrm{mr}\right)\end{array}$} & \multicolumn{3}{|c|}{$\begin{array}{c}\text { ACK } 300 \text { мг } \\
\text { (DDD* - } 1 \text { табл.) }\end{array}$} \\
\hline $\begin{array}{l}\text { Коплавікс®, табл. в/о, } 75 \text { мг/75 мг } \\
\text { № } 28, \text { Санофрі-Авентіс Україна, } \\
\text { Україна }\end{array}$ & 6 & $\frac{611,47}{21,84}$ & $\begin{array}{l}\text { Аспірин кардіо®, табл. в/о, } \\
\text { кишковорозч., по } 300 \text { мг } \\
\text { № 28, Байєр АГ, Німеччина }\end{array}$ & 9 & $\frac{75,25}{2,69}$ \\
\hline $\begin{array}{l}\text { Плавікс®, табл. в/о, по } 75 \text { мг № 28, } \\
\text { Санофрі-Авентіс Україна, Україна }\end{array}$ & 6 & $\frac{584,03}{20,86}$ & $\begin{array}{l}\text { Аспенорм, табл. в/о, } \\
\text { кишковорозч. по } 300 \text { мг } \\
\text { № 20, ТОВ «Фармекс Груп», } \\
\text { Україна }\end{array}$ & 2 & $\frac{43,89}{2,19}$ \\
\hline $\begin{array}{l}\text { Клопідогрель-Зентіва, табл. в/о, } \\
\text { по } 75 \text { мг № 30, Зентіва, Чеська } \\
\text { Республіка }\end{array}$ & 6 & $\frac{97,07}{3,24}$ & \multicolumn{3}{|c|}{$\begin{array}{c}\text { ACK } 150 \text { мг } \\
\text { (DDD* - } 1 \text { табл.) }\end{array}$} \\
\hline $\begin{array}{l}\text { Агрель } 75 \text { мг, табл. в/о, по } 75 \text { мг } \\
\text { № 28, Асіно Фарма АГ, Швейцарія }\end{array}$ & 5 & $\frac{89,36}{3,19}$ & $\begin{array}{l}\text { Кардіомагніл, табл. в/о, по } \\
150 \text { мг № 30, Такеда ГмбХ, } \\
\text { Австрія }\end{array}$ & 13 & $\frac{39,57}{1,32}$ \\
\hline $\begin{array}{l}\text { Клопідогрель-Зентіва, табл. в/о, } \\
\text { по } 75 \text { мг № 90, Зентіва, Чеська } \\
\text { Республіка }\end{array}$ & 5 & $\frac{257,3}{2,86}$ & $\begin{array}{l}\text { Акард, табл. кишковорозч., } \\
\text { по } 150 \text { мг № 50, } \\
\text { «Польфрарма» С.А., Польща }\end{array}$ & 6 & $\frac{66,14}{1,32}$ \\
\hline $\begin{array}{l}\text { Медогрель, табл. в/о, по } 75 \text { мг } \\
\text { № 30, Медокемі лТД, Кіпр }\end{array}$ & 6 & $\frac{83,07}{2,77}$ & $\begin{array}{l}\text { Кардіомагніл, табл. в/о, по } \\
150 \text { мг № 100, Такеда ГмбХ, } \\
\text { Австрія }\end{array}$ & 13 & $\frac{92,70}{0,93}$ \\
\hline $\begin{array}{l}\text { Тромбонет®, табл. в/о, по } 75 \text { мг } \\
\text { № 30, ТзОВ «Дослідний завод } \\
\text { «ДНЦЛЗ», Україна }\end{array}$ & 13 & $\frac{75,60}{2,52}$ & \multicolumn{3}{|c|}{$\begin{array}{c}\text { АCK } 100 \text { мг } \\
\text { (DDD* - } 1 \text { табл.) }\end{array}$} \\
\hline $\begin{array}{l}\text { Клопідогрель, табл. в/о, по } 75 \text { мг } \\
\text { № 10, ТзОВ «Дослідний завод } \\
\text { «ДНЦЛ», Україна }\end{array}$ & 4 & $\frac{24,80}{2,48}$ & $\begin{array}{l}\text { Аспірин кардіо®, табл. в/о, } \\
\text { кишковорозч. по } 100 \text { мг } \\
\text { № 28, Байєр АГ, Німеччина }\end{array}$ & 11 & $\frac{50,20}{1,79}$ \\
\hline $\begin{array}{l}\text { Нугрел, табл. в/о, по } 75 \text { мг № 30, } \\
\text { Мікро Лабс Лімітед, Індія }\end{array}$ & 5 & $\frac{71,58}{2,39}$ & $\begin{array}{l}\text { Аспірин кардіо®, табл. в/о, } \\
\text { кишковорозч., по } 100 \text { мг } \\
\text { № 56, Байєр АГ, Німеччина }\end{array}$ & 9 & $\frac{84,75}{1,51}$ \\
\hline $\begin{array}{l}\text { Клопідогрель-Тева, табл. в/о, по } \\
75 \text { мг № 30, Тева Фармацевтікал } \\
\text { Індастріз Лтд., Ізраїль }\end{array}$ & 7 & $\frac{70,94}{2,36}$ & $\begin{array}{l}\text { Ацекор кардіо, табл. } \\
\text { кишковорозч. по } 100 \text { мг № 50, } \\
\text { ТОВ Науково-виробнича } \\
\text { фрірма «Мікрохім», Україна }\end{array}$ & 10 & $\frac{48,60}{0,97}$ \\
\hline $\begin{array}{l}\text { Лопірел, табл. в/о, по } 75 \text { мг № 30, } \\
\text { Актавіс Груп, Ісландія }\end{array}$ & 6 & $\frac{68,86}{2,29}$ & $\begin{array}{l}\text { Ацекор кардіо, табл. } \\
\text { кишковорозч. по } 100 \text { мг } \\
\text { № 100, ТОВ Науково- } \\
\text { виробнича фрірма } \\
\text { «Мікрохім», Україна }\end{array}$ & 9 & $\frac{41,43}{0,41}$ \\
\hline
\end{tabular}

ISSN 2312-0967. Фармацевтичний часопис. 2018. № 3 
Фармакоекономіка

Pharmacoeconomics

Продовження табл. 1

\begin{tabular}{|c|c|c|c|c|c|}
\hline 1 & 2 & 3 & 4 & 5 & 6 \\
\hline $\begin{array}{l}\text { Клопідогрель, табл. в/о, по } 75 \text { мг } \\
\text { № 30, ТзОВ «Дослідний завод } \\
\text { «ДНЦлЗ», Україна }\end{array}$ & 3 & $\frac{67,64}{2,25}$ & \multicolumn{3}{|c|}{$\begin{array}{c}\text { ACK } 75 \text { мг } \\
\text { (DDD* - } 1 \text { табл.) }\end{array}$} \\
\hline $\begin{array}{l}\text { Лопірел, табл. в/о, по } 75 \text { мг № 90, } \\
\text { Актавіс Груп, Ісландія }\end{array}$ & 6 & $\frac{198,31}{2,20}$ & $\begin{array}{l}\text { Тромбо АСС } 75 \text { м2, табл. в/о, } \\
\text { кишковорозч. по } 75 \text { мг № 30, } \\
\text { Валеант Фармасьютикалз, } \\
\text { Україна }\end{array}$ & 4 & $\frac{54,57}{1,82}$ \\
\hline $\begin{array}{l}\text { Клодія, табл. в/о, по } 75 \text { мг № 30, } \\
\text { Алвоген ІПКО, Люксембург }\end{array}$ & 7 & $\frac{65,49}{2,18}$ & $\begin{array}{l}\text { Кардіомагніл, табл. в/о, по } \\
75 \text { мг № 30, Такеда ГмбХ, } \\
\text { Австрія }\end{array}$ & 10 & $\frac{43,03}{1,43}$ \\
\hline $\begin{array}{l}\text { Клопідогрел-Тева, табл. в/о, по } \\
75 \text { мг № 90, Тева Фармацевтікал } \\
\text { Індастріз Лтд., Ізраїль }\end{array}$ & 7 & $\frac{195,02}{2,17}$ & $\begin{array}{l}\text { Акард, табл. кишковорозч., } \\
\text { по } 75 \text { мг № 50, «Польфарма» } \\
\text { С.А., Польща }\end{array}$ & 7 & $\frac{61,62}{1,23}$ \\
\hline $\begin{array}{l}\text { Плазеп, табл., в/о, по } 75 \text { мг № 30, } \\
\text { МСН Лабораторіс Пвт. Лтд., Індія }\end{array}$ & 5 & $\frac{64,87}{2,16}$ & $\begin{array}{l}\text { Кардіомагніл, табл. в/о, по } \\
75 \text { мг № 100, Такеда ГмбХ, } \\
\text { Австрія }\end{array}$ & 11 & $\frac{87,09}{0,87}$ \\
\hline $\begin{array}{l}\text { Платогріл®, табл. в/о, по } 75 \text { мг } \\
\text { № 28, ТОВ «Кусум Фарм», Україна }\end{array}$ & 8 & $\frac{58,04}{2,07}$ & $\begin{array}{l}\text { Лоспирин®, табл. в/о, кишко- } \\
\text { ворозч., по } 75 \text { мг № 30, ТОВ } \\
\text { «Кусум Фарм», Україна }\end{array}$ & 11 & $\frac{25,29}{0,84}$ \\
\hline $\begin{array}{l}\text { Атерокард, табл. в/о, по } 75 \text { мг } \\
\text { № 10, ПАТ «Київський вітамінний } \\
\text { завод», Україна }\end{array}$ & 10 & $\frac{20,52}{2,05}$ & $\begin{array}{l}\text { Акард, табл. кишковорозч., } \\
\text { по } 75 \text { мг № 100, } \\
\text { «Польфрарма» С.А., Польща }\end{array}$ & 4 & $\frac{80,36}{0,80}$ \\
\hline $\begin{array}{l}\text { Атерокард, табл. в/о, по } 75 \text { мг } \\
\text { № 40, ПАТ «Київський вітамінний } \\
\text { завод», Україна }\end{array}$ & 11 & $\frac{75,25}{1,88}$ & 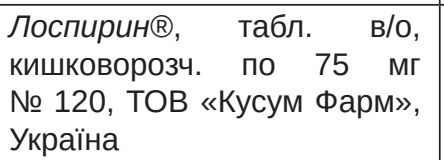 & 12 & $\frac{71,72}{0,59}$ \\
\hline $\begin{array}{l}\text { Атрогрел, табл. в/о, по } 75 \text { мг } \\
\text { № 30, ПАТ «НВЦ «Борщагівський } \\
\text { ХФЗ», Україна }\end{array}$ & 12 & $\frac{54,46}{1,82}$ & $\begin{array}{l}\text { Кардісейв®, табл. в/о, } \\
75 \text { мг № 50, пАТ «Фармак», } \\
\text { Україна }\end{array}$ & 8 & $\frac{26,25}{0,53}$ \\
\hline $\begin{array}{l}\text { Платогріл®, табл. в/о, по } 75 \text { мг } \\
\text { № 84, ТОВ «Кусум Фарм», Україна }\end{array}$ & 8 & $\frac{153,03}{1,82}$ & $\begin{array}{r}\text { Комбіновані Л3 (AC } \\
\left(\mathrm{DDD}^{*}-1 \mathrm{Ta}\right.\end{array}$ & 15 & \\
\hline $\begin{array}{l}\text { Фламогрель 75, табл. в/о, по } 75 \text { мг } \\
\text { № 100, Ананта Медікер, Велика } \\
\text { Британія }\end{array}$ & 7 & $\frac{163,81}{1,64}$ & $\begin{array}{l}\text { Магнікор, табл. в/о, фрорте } \\
\text { № 30, ПАТ «Київський } \\
\text { вітамінний завод», Україна }\end{array}$ & 12 & $\frac{24,48}{0,82}$ \\
\hline $\begin{array}{l}\text { Атерокард, табл. в/о, по } 75 \text { мг } \\
\text { № 70, ПАТ «Київський вітамінний } \\
\text { завод», Україна }\end{array}$ & 10 & $\frac{110,70}{1,58}$ & $\begin{array}{l}\text { Магнікор, табл. в/о, фрорте } \\
\text { № 100, ПАТ «Київський } \\
\text { вітамінний завод», Україна }\end{array}$ & 11 & $\frac{75,01}{0,75}$ \\
\hline $\begin{array}{l}\text { Тромбонет®, табл. в/о, по } 75 \text { мг } \\
\text { № } 60, \text { ПАТ «Фармак», Україна }\end{array}$ & 12 & $\frac{94,01}{1,57}$ & & & \\
\hline \multicolumn{3}{|l|}{$\begin{array}{c}\text { Трифолузал } \\
\left(D^{*}-600 \text { мг) }\right.\end{array}$} & \multicolumn{3}{|c|}{$\begin{array}{c}\text { Тиклопідин } \\
\text { (DDD* - } 500 \text { мг) }\end{array}$} \\
\hline $\begin{array}{l}\text { Дісгрен, капс. по } 300 \text { мг № 30, Х. } \\
\text { Уріак і Компанія, С.А., Іспанія }\end{array}$ & 4 & $\frac{313,31}{20,89}$ & $\begin{array}{l}\text { Іпатон®, табл. в/о, по } 250 \text { мг } \\
\text { № 20, ЗАТ Фармацевтичний } \\
\text { завод «ЕГІС», Угорщина }\end{array}$ & 6 & $\frac{167,50}{8,38}$ \\
\hline
\end{tabular}

Примітка. * - величина DDD на підставі джерела [14].

Як видно з даних таблиці 1, максимальна вартість DDD (понад 20 грн) притаманна для 2-х ТН клопідогрелю (Плавікс, Коплавікс) та 1 ТН трисрлузалу (Дісгрен). Мінімальна вартість DDD (менш ніж 2 грн) характерна для майже 90 \% ТН АСК (наприклад, Ацекор кардіо,
Кардіомагніл, Лоспірин, Акард тощо), а також для таких ТН клопідогрелю, як Атерокард, Атрогрел, Платогрил, Фламогрель 75 і Тромбонет. Для інших ЛЗ клопідогрелю та 2-х ТН АСК (Аспірин кардіо, табл. в/о, кишковорозч. по 300 мг № 28 та Аспенорм) вартість DDD була в меж-

ISSN 2312-0967. Pharmaceutical review. 2018. № 3 
aх 2 - 3 грн. Вартість DDD для тиклопідину (Іпатон) становила дещо більше ніж 8 грн.

Дані таблиці 2 показують, що найбільш економічно доступними $є$ TH ACK, оскільки для більш ніж половини 3 них вартість DDD менше 1 грн. Вартість DDD для майже усіх ТН клопідогрелю та 9 аналізованих ТН АСК знаходиться в межах 1 - 5 грн. Низька економічна доступність характерна для 2-х ТН клопідогрелю (Плавікс та Коплавікс), а також ТН трифлузалу (Дісгрен).

Варто зазначити, що серед досліджуваних АА відсутні ЛЗ в 19 матричних полях за співвідношенням «вартість DDD і кількість ТН AА», зокрема Л3, що характеризувалися би найнижчою вартістю і найвищою кількістю ТН. Співвідношенням «найнижча вартість DDD - середня кількість ТН» і «нижче середньої вартість і середня кількість ТН» характерне для 10 і 9 ТН АСК відповідно. У свою чергу, 22 ТН клопідогрелю вигідно вирізняється за співвідношенням «нижче середньої вартості DDD - найвища кількість ТН».

В аналізованому періоді для 4 ТН клопідогрелю, 10 лз АСК, ТН тиклопідину та трифлузалу Kliq був меншим 0,15, тобто коливання цін є незначними і ціни коректні відносно споживача (табл. 3). Для 20 Л3

Таблиця 2. Матрична проекція розподілу досліджуваних антиагрегантів за їх вартістю DDD і кількістю торгових назв

\begin{tabular}{|c|c|c|c|c|c|}
\hline \multirow[b]{2}{*}{ Вартість DDD, грн } & \multicolumn{5}{|c|}{ Кількість ТН досліджуваних АА } \\
\hline & $\begin{array}{l}\text { найнижча } \\
(1 \mathrm{TH})\end{array}$ & $\begin{array}{c}\text { нижче } \\
\text { середньої } \\
(1-5 \text { TH })\end{array}$ & $\begin{array}{c}\text { середня } \\
(5-10 \mathrm{TH})\end{array}$ & $\begin{array}{c}\text { вище } \\
\text { середньої } \\
(10-20 \text { TH })\end{array}$ & $\begin{array}{c}\text { найвища } \\
\text { (понад } 20 \mathrm{TH} \text { ) }\end{array}$ \\
\hline $\begin{array}{l}\text { Найнижча } \\
\text { (до } 1 \text { грн) }\end{array}$ & & & $\begin{array}{c}\mathrm{ACK} \\
(10 \mathrm{TH})\end{array}$ & & \\
\hline $\begin{array}{c}\text { Нижче середньої } \\
(1-5 \mathrm{TH})\end{array}$ & & & $\begin{array}{c}\text { ACK } \\
(9 \mathrm{TH})\end{array}$ & & $\begin{array}{c}\text { Клопідогрель } \\
(22 \mathrm{TH})\end{array}$ \\
\hline $\begin{array}{c}\text { Середня } \\
(5-10 \text { грн) } \\
\end{array}$ & Тиклопідин & & & & \\
\hline $\begin{array}{c}\text { Вище середньої } \\
(10-20 \text { грн) }\end{array}$ & & & & & \\
\hline $\begin{array}{c}\text { Найвища } \\
\text { (понад } 20 \text { грн) }\end{array}$ & Триорлузал & $\begin{array}{c}\text { Клопідогрель } \\
\text { (2 ТН) }\end{array}$ & & & \\
\hline
\end{tabular}

Таблиця 3. Розподіл антиагрегантів за величиною коефіцієнта ліквідності ціни

\begin{tabular}{|c|c|c|}
\hline \multicolumn{3}{|c|}{ Значення коесріцієнта ліквідності ціни, Kliq } \\
\hline До 0,15 & $0,16-0,49$ & $0,50-0,99$ \\
\hline \multicolumn{3}{|c|}{ Клопідогрель } \\
\hline $\begin{array}{l}\text { Клопідогрель-Зентіва, табл., в/о, по } 75 \text { мг } \\
\text { № 30, Зентіва, Чеська Республіка }\end{array}$ & $\begin{array}{l}\text { Коплавікс } ® \text {, табл., в/о, } 75 \text { мг/75 } \\
\text { мг № 28, Санофрі-Авентіс } \\
\text { Україна, Україна }\end{array}$ & - \\
\hline $\begin{array}{l}\text { Агрель } 75 \text { мг, табл., в/о, по } 75 \text { мг № 28, } \\
\text { Асіно Фарма АГ, Швейцарія та ін. }\end{array}$ & $\begin{array}{l}\text { Плавікс } ® \text {, табл., в/о, по } 75 \text { мг } \\
\text { № 28, Санофрі-Авентіс Україна } \\
\text { (Україна) та ін. }\end{array}$ & - \\
\hline Всього: 4 TH & Всього: $20 \mathrm{TH}$ & \\
\hline \multicolumn{3}{|c|}{ ACK } \\
\hline $\begin{array}{l}\text { Аспірин кардіо®, табл., в/о, кишковорозч., } \\
\text { по } 300 \text { мг № 28, Байєр АГ, Німеччина }\end{array}$ & $\begin{array}{l}\text { Кардіомагніл, табл., в/о, по } 150 \\
\text { мг № 100, Такеда ГмбХ, Австрія }\end{array}$ & $\begin{array}{l}\text { Кардіомагніл, табл., в/о, по } 150 \\
\text { мг № 30, Такеда ГмбХ, Австрія }\end{array}$ \\
\hline $\begin{array}{l}\text { Аспенорм, табл., в/о, кишковорозч. } \\
\text { по } 300 \text { мг № 20, ТОВ «Фармекс Груп, } \\
\text { Україна та ін. }\end{array}$ & $\begin{array}{l}\text { Кардіомагніл, табл., в/о, по } 75 \\
\text { мг № 30, Такеда ГмбХ, Австрія } \\
\text { та ін. }\end{array}$ & $\begin{array}{l}\text { Аспірин кардіо®, табл., в/о, } \\
\text { кишковорозч. по } 100 \text { мг № 28, } \\
\text { Байєр АГ, Німеччина та ін. }\end{array}$ \\
\hline Всього: $10 \mathrm{TH}$ & Всього: 4 TH & Всього: 5 TH \\
\hline \multicolumn{3}{|c|}{ Тиклопідин } \\
\hline $\begin{array}{l}\text { Іпатон®, табл., в/о, по } 250 \text { мг № 20, ЗАТ } \\
\text { Фармацевтичний завод «ЕГІС», Угорщина }\end{array}$ & - & - \\
\hline \multicolumn{3}{|c|}{ Трисрлузал } \\
\hline $\begin{array}{l}\text { Дісгрен, капс. по } 300 \text { мг № 30, Х. Уріак і } \\
\text { Компанія, С.А., Іспанія }\end{array}$ & - & - \\
\hline
\end{tabular}

ISSN 2312-0967. Фармацевтичний часопис. 2018. № 3 
клопідогрелю та 4 л3 ACK Kliq знаходився у межах від 0,15 до 0,49. Це свідчить про значний розмах цін на вказані Л3 і некоректність їх відносно споживача. Для 5 Л3 ACK Kliq був вищим 0,5, тобто спостерігалася більш ніж 50 \% різниця у цінах.

Таким чином, на момент дослідження ціни на більшість АА були коректними відносно споживачів. Висока цінова конкуренція притаманна 5 TH АCK (Кардіомагніл, табл., в/о, по 150 мг № 30, Такеда ГмбХ, Австрія; Аспірин кардіо®, табл., в/о, кишковорозч. по
100 мг № 28, Байєр АГ, Німеччина; Ацекор кардіо, табл. кишковорозч. по 100 мг № 100, ТОВ Наукововиробнича орірма «Мікрохім», Україна; Магнікор, табл., в/о, фрорте № 30 та №100, ПАТ «Київський вітамінний завод», Україна ).

Далі ми проаналізували номенклатуру лз клопідогрелю в рамках урядової програми «Доступні ліки». Встановлено, що реєстр ЛЗ, вартість яких підлягає відшкодуванню, включає 23 ТН клопідогрелю. Результати аналізу їх цін подано в таблиці 4. Як видно 3

Таблиця 4. Результати аналізу роздрібних цін на лікарські засоби клопідогрелю в рамках урядової програми «Доступні ліки»

\begin{tabular}{|c|c|c|c|c|c|c|}
\hline Торгова назва лікарського засобу & $\begin{array}{c}\text { Оптово- } \\
\text { відпускна } \\
\text { ціна за } \\
\text { упаковку, } \\
\text { грн }\end{array}$ & $\begin{array}{c}\text { Роз- } \\
\text { дрібна } \\
\text { ціна за } \\
\text { упаковку, } \\
\text { грн }\end{array}$ & \begin{tabular}{|c|} 
Розмір \\
відшкоду- \\
вання \\
за упа- \\
ковку лз, \\
грн
\end{tabular} & $\begin{array}{c}\text { Сума до- } \\
\text { плати за } \\
\text { упаковку, } \\
\text { грн }\end{array}$ & \begin{tabular}{|c|} 
Частка \\
відшкоду- \\
вання \\
за упа- \\
ковку лз, \\
\%
\end{tabular} & $\begin{array}{c}\text { Частка } \\
\text { доплати } \\
\text { за упа- } \\
\text { ковку, \% }\end{array}$ \\
\hline 1 & 2 & 3 & 4 & 5 & 6 & 7 \\
\hline $\begin{array}{l}\text { Клопідогрель-Тева табл. в/о, по } 75 \text { мг № 90, Тева, } \\
\text { Ізраїль }\end{array}$ & 177,30 & 239,98 & 178.38 & 61,60 & 74,3 & 25,7 \\
\hline $\begin{array}{l}\text { Лопірел, табл. в/о по } 75 \text { мг, № 90, Актавіс лтД, } \\
\text { Мальта }\end{array}$ & 177,30 & 239,98 & 178.38 & 61,60 & 74,3 & 25,7 \\
\hline $\begin{array}{l}\text { Фламогрель 75, табл. в/о, по } 75 \text { мг № 100, Фламінго } \\
\text { Фармасьютікалс Лтд, Індія }\end{array}$ & 164,00 & 221,98 & 198,20 & 23,78 & 89,3 & 10,7 \\
\hline $\begin{array}{l}\text { Атерокард, табл. в/о, по } 75 \text { мг № 70, ПАТ } \\
\text { «Київський вітамінний завод», Україна }\end{array}$ & 102,50 & 138,74 & 138,74 & 0 & 100,0 & 0 \\
\hline $\begin{array}{l}\text { Медогрель, табл. в/о по } 75 \text { мг № 30, Актавіс ЛтД, } \\
\text { Мальта }\end{array}$ & 88,32 & 119,55 & 59,46 & 60,09 & 49,7 & 50,3 \\
\hline $\begin{array}{l}\text { Плагрил, табл. в/о по } 75 \text { мг № 30, Д-р Редді'с } \\
\text { Лабораторіс Лтд, Індія }\end{array}$ & 84,20 & 113,97 & 59,46 & 54,51 & 52,2 & 47,8 \\
\hline $\begin{array}{l}\text { Агрель } 75 \text { мг; табл. в/о } 75 \text { мг № 28, Ацино Фарма АГ, } \\
\text { Швейцарія }\end{array}$ & 81,25 & 109,98 & 55,50 & 54,48 & 50,5 & 49,5 \\
\hline $\begin{array}{l}\text { Тромбонет, табл. в/о, по } 75 \text { мг № 30, ПАТ } \\
\text { «Фармак», Україна }\end{array}$ & 71,00 & 96,10 & 59,46 & 36,64 & 61.9 & 38,1 \\
\hline $\begin{array}{l}\text { Тромбонет, табл. в/о, по } 75 \text { мг № 60, ПАТ } \\
\text { «Фармак», Україна }\end{array}$ & 88,75 & 120,13 & 118,92 & 1,21 & 98,9 & 1,1 \\
\hline $\begin{array}{l}\text { Атерокард, табл. в/о, по } 75 \text { мг № 40, ПАТ } \\
\text { «Київський вітамінний завод» }\end{array}$ & 70,00 & 94,75 & 79,28 & 15,47 & 83,7 & 16,3 \\
\hline $\begin{array}{l}\text { Клопідогрель-Тева, табл. в/о, по } 75 \text { мг № 30, Тева, } \\
\text { Ізраїль }\end{array}$ & 64,50 & 87,30 & 59,46 & 27,84 & 68,1 & 31,9 \\
\hline $\begin{array}{l}\text { Лопірел, табл. в/о по } 75 \text { мг, № 30, Актавіс ЛТД, } \\
\text { Мальта }\end{array}$ & 64,50 & 87,30 & 59,46 & 27,84 & 68,1 & 31,9 \\
\hline $\begin{array}{l}\text { Нугрел, табл. в/о, по } 75 \text { мг № 30, Мікро лабс. } \\
\text { Лімітед, Індія }\end{array}$ & 64,00 & 86,63 & 59,46 & 27,17 & 68,6 & 31,4 \\
\hline $\begin{array}{l}\text { Клопідогрель-Фармекс, табл в/о, по } 75 \text { мг № 30, ТОВ } \\
\text { «Фармекс Груп», Україна }\end{array}$ & 61,50 & 83,24 & 59,46 & 23,78 & 71,4 & 28,6 \\
\hline $\begin{array}{l}\text { Клопідогрель табл. в/о, по } 75 \text { мг № 30, ТзОВ } \\
\text { «Дослідний завод «ДНЦЛЗ», Україна }\end{array}$ & 61,50 & 83,24 & 59,46 & 23,78 & 71,4 & 28,6 \\
\hline Клодія, табл. в/о 75 мг № 30, Фарматен С.А, Греція & 61,20 & 82,84 & 59,46 & 23,38 & 71,8 & 28,2 \\
\hline $\begin{array}{l}\text { Плазеп, табл. в/о, по } 75 \text { мг № 30, МСН Лабораторіс } \\
\text { Пвт.Лтд., Індія }\end{array}$ & 58,00 & 78,51 & 59,46 & 19,05 & 75,7 & 24,3 \\
\hline $\begin{array}{l}\text { Платогрил, табл. в/о по } 75 \text { мг № 28, ТОВ «Кусум } \\
\text { Фарм», Україна }\end{array}$ & 53,90 & 72,96 & 55,50 & 17,46 & 76,1 & 23,9 \\
\hline $\begin{array}{l}\text { Платогрил, табл. в/о по } 75 \text { мг № 84, ТОВ «Кусум } \\
\text { Фарм», Україна }\end{array}$ & 140,00 & 189,50 & 166,49 & 23,01 & 87,9 & 12,1 \\
\hline
\end{tabular}

ISSN 2312-0967. Pharmaceutical review. 2018. № 3 
Продовження табл. 4

\begin{tabular}{|c|c|c|c|c|c|c|}
\hline 1 & 2 & 3 & 4 & 5 & 6 & 7 \\
\hline $\begin{array}{l}\text { Атрогрел, табл. в/о, по } 75 \text { мг № 30, ПАТ } \\
\text { «Борщагівський ХФЗ», Україна }\end{array}$ & 52,37 & 70,89 & 59,46 & 11,43 & 83,8 & 16,2 \\
\hline $\begin{array}{l}\text { Онеклапз, табл. в/о, по } 75 \text { мг № 30, Ауробіндо } \\
\text { Фарма Лімітед (Юніт ІІІ), Індія }\end{array}$ & 45,00 & 60,91 & 59,46 & 1,45 & 97,6 & 2,4 \\
\hline $\begin{array}{l}\text { Клопідогрель табл. в/о, по } 75 \text { мг № 10, ТзОВ } \\
\text { «Дослідний завод «ДНЦЛЗ», Україна }\end{array}$ & 22,96 & 31,08 & 19,82 & 11,26 & 63,7 & 36,3 \\
\hline $\begin{array}{l}\text { Атерокард, табл. в/о, по } 75 \text { мг № 10, ПАТ } \\
\text { «Київський вітамінний завод», Україна }\end{array}$ & 19,00 & 25,72 & 19,82 & 5,90 & 77,0 & 23,0 \\
\hline
\end{tabular}

даних таблиці 4, такий Л3, як Атерокард табл. в/о, по 75 мг № 70 (виробник ПАТ «Київський вітамінний завод», Україна), хворі можуть отримати безкоштовно. При придбанні лз Тромбонет, табл. в/о, по 75 мг № 60 (виробник ПАТ «Фармак», Україна); Онеклапз, табл., в/о, по 75 мг № 30 (виробник Ауробіндо Фарма Лімітед (Юніт III), Індія); Фламогрель 75, табл. в/о, по 75 мг № 100 (виробник Фламінго Фармасьютікалс Лтд, Індія) та Платогрил, табл., в/о по 75 мг № 84 (виробник ТОВ «Кусум Фарм», Україна) споживачі повинні оплатити 1,1\%, 2,4\%, 10,7\%, 12,1\% вартості відповідно.

Щодо 2 Л3 (Атерокард, табл. в/о, по 75 мг № 40 (виробник ПАТ «Київський вітамінний завод») та Атрогрел, табл. в/о, по 75 мг № 30 (виробник ПАТ «Борщагівський ХФЗ») за урядовою програмою відшкодовується близько 84 \% вартості.

При придбанні Л3 Клопідогрель-Тева табл. в/о, по 75 мг № 90 (виробник Тева, Ізраїль); Лопірел, табл. в/о по 75 мг № 90 та № 30 (виробник Актавіс лТД, Мальта); Клопідогрель-Фармекс, табл в/о, по 75 мг № 30 (виробник ТОВ «Фармекс Груп», Україна); Клопідогрель табл. в/о, по 75 мг № 30 (виробник ТзОВ «Дослідний завод «ДНЦЛЗ», Україна); Клодія, табл. в/о 75 мг № 30 (виробник Фарматен С.А, Греція); Плазеп, табл. в/о, по 75 мг № 30 (виробник МСH Лабораторіс Пвт.Лтд., Індія); Платогрил, табл. в/о по 75 мг № 28 (виробник ТОВ «Кусум Фарм», Україна); Атерокард, табл. в/о, по 75 мг № 10 (виробник ПАТ «Київський вітамінний завод», Україна); Тромбонет, табл. в/о, по 75 мг № 30 (виробник ПАТ «Фармак», Україна); Клопідогрель-тева, табл. в/о, по 75 мг № 30 (виробник Тева, Ізраїль); Нугрел, табл. в/о, по 75 мг № 30 (виробник Мікро лабс. Лімітед, Індія) та Клопі- догрель табл. в/о, по 75 мг № 10 (виробник ТзОВ «Дослідний завод «ДНЦЛЗ», Україна) пацієнт відшкодовує 20 - 40 \% вартості ЛЗ.

Найбільш дороговартісними для споживача $€ 3$ л3, а саме: Медогрель, табл. в/о по 75 мг № 30 (виробник Актавіс лтД, Мальта); Плагрил, табл. в/о по 75 мг № 30 (виробник Д-р Редді'с Лабораторіс Лтд, Індія) та Агрель 75 мг; табл. в/о 75 мг № 28 (виробник Ацино Фарма АГ, Швейцарія). За них потрібно оплатити майже 50 \% вартості.

Таким чином, один ЛЗ з аналізованої групи пацієнти можуть отримати безкоштовно, для 19 ЛЗ відшкодовується 61,9 - 98,9 \% їх вартості, а за 3 л3 споживачі повинні доплатити близько половини їх вартості. Частка доплати за упаковку Лз коливається у межах $0-49,5 \%$.

Висновки. 1. Встановлено, що продуктова кон'юнктура AА на момент дослідження сумарно налічувала 62 ТН Л3.

2. Виявлено, що серед АА найбільш економічно доступними є ЛЗ АСК, оскільки для більш ніж половини 3 них вартість DDD є менше однієї гривні. Низька економічна доступність характерна для 2-х ТН клопідогрелю (Плавікс та Коплавікс), а також ТН трифрлузалу (Дісгрен).

3. Аналіз значень коефріцієнта ліквідності ціни засвідчив, що на момент дослідження ціни на більшість AА були коректними відносно споживачів, а висока цінова конкуренція притаманна 5 ЛЗ АСК.

4. У межах урядової програми «Доступні ліки» одну ТН клопідогрелю пацієнти можуть отримати безкоштовно, для 19 ТН відшкодовується 61,9 98,9 \% їх вартості, а за 3 ТН споживачі повинні доплатити близько половини їх вартості.

\section{АНТИАГРЕГАНТЫ ПРИ ИШЕМИЧЕСКОМ ИНСУЛЬТЕ С ТОЧКИ ЗРЕНИЯ СОЦИАЛЬНОЙ ФАРМАЦИИ}

\section{О. Р. Левицкая, Б. П. Громовик}

Львовский национальный медицинский университет имени Данила Галицкого levytska.oksana@gmail.com,hromovyk@gmail.com

Цель работы. Ситуативный анализ номенклатуры зарегистрированных в Украине антиагрегантов (AА), их продуктовой и ценовой конъюнктуры, а также экономической доступности.

ISSN 2312-0967. Фармацевтичний часопис. 2018. № 3 
Материалы и методы. Данные из Государственного реестра лекарственных средств (ЛС) Украины, информация с сайта «Аптека online.ua». Рассчитывали коэффрициент ликвидности цены (Kliq), стоимость установленной суточной дозы (DDD), анализировали розничную стоимость ЛС клопидогреля в рамках программы «Доступные лекарства».

Результаты и обсуждение. Ситуативный анализ продуктовой конъюнктуры АА позволил установить 32 зарегистрированные торговые названия (ТH) моно- и 2 ТН комбинированных ЛС клопидогреля; 22 TH моно- и 4 комбинированных ЛС АСК; по одному ЛС тиклопидина и трифлузала. Максимальная стоимость DDD (более 20 грн) характерна для 2-х ТН клопидогреля и одной ТН трифрлузала. Минимальная стоимость DDD (менее 2 грн) характерна для почти 90 \% ТН АСК, а также для 5-ти ТН клопидогреля. Для 4 ТН клопидогреля, 10 TH ACK, ТН тиклопидина и трифлузала Kliq был меньше 0,15; для 20 ЛС клопидогреля и 4 ЛС АСК - находился в пределах 0,15 - 0,49, а для 5 ЛС АСК был выше 0,5. Выяснено, что реестр ЛС, стоимость которых подлежит возмещению (в рамках правительственной программы «Доступные лекарства»), включает 23 ТН клопидогреля. Процент доплаты за упаковку лс колеблется в пределах $0-49,5 \%$.

Выводы. Установлено, что продуктовая конъюнктура АА на момент исследования суммарно насчитывала 62 ТН ЛС. Выявлено, что среди АА наиболее экономически доступными являются ЛС АСК, поскольку для более чем половины из них стоимость DDD меньше 1 грн. Низкая экономическая доступность характерна для 2-х ТН клопидогреля (плавикс и коплавикс), а также ТН трифрлузала (дисгрен). Анализ значений коэфрфициента ликвидности цены показал, что на момент исследования цены на большинство АА были корректными по отношению к потребителям, а высокая ценовая конкуренция присуща 5 ЛС АСК. В рамках правительственной программы «Доступные лекарства» одно ТН клопидогреля пациенты могут получить бесплатно, для 19 ТН возмещается 61,9 - 98,9 \% их стоимости, а за 3 ТН потребители должны доплатить около половины их стоимости.

Ключевые слова: ишемический инсульт; антиагреганты; социальная срармация.

\title{
ANTIPLATELET DRUGS IN THE TREATMENT OF ISCHEMIC STROKE IN THE CONTEXT OF SOCIAL PHARMACY
}

\author{
O. R. Levytska, B. P. Hromovyk
}

Danylo Halytsky Lviv National Medical University

levytska.oksana@gmail.com, hromovyk@gmail.com

The aim of the work. Situational analysis of the nomenclature of registered antiplatelet drugs (APD) in Ukraine, their product and price conditions, and also economic availability.

Materials and Methods. Data from the State Register of Medicinal Products of Ukraine, information from the website "Pharmacy online.ua". The price liquidity ratio (Kliq) and the cost of defined daily dose (DDD) were calculated, and the retail cost of Clopidogrel trade names as the part of state program "Available drugs" was analyzed.

Results and Discussion. The situational analysis of the product condition of APD established 32 registered trade names (TN) of mono preparations and 2 TN of combined medicines of Clopidogrel; 22 mono preparations and 4 combined drugs of Acetylsalicylic acid (ASA); 1 TN of Ticlopidine and 1 TN of Triflusal. The maximum cost of DDD (more than $20 \mathrm{UAH}$ ) is typical for 2 TN of Clopidogrel and 1 TN of Triflusal. The minimum cost of DDD (less than $2 \mathrm{UAH}$ ) is characteristic for almost $90 \%$ of ASA TN, as well as for 5 Clopidogrel TN. The Kliq for 4 Clopidogrel TN, 10 ASA TN, TN Ticlopidine and Triflusal was less than 0.15 ; for 20 drugs of Clopidogrel and 4 drugs of ASA - was within the range of $0.15-0.49$, and for 5 ASA TN was higher than 0.5 . It was found that the register of drugs, the cost of which is subject to reimbursement (within the government program "Available drugs"), includes 23 TN of Clopidogrel. The percentage of payment to the full amount for package of medicine varies from 0 to $49.5 \%$.

Conclusions. It was established that at the time of the study, the total APD condition consisted from 62 TN of medicines. It was revealed that among APD the most economically affordable are ASA TN, because for more than half of them the cost of DDD is less than $1 \mathrm{UAH}$. Low economic availability is typical of 2 Clopidogrel TN (Plavix and Koplavix), as well as Triflusal TN (Disgren). Analysis of the values of the liquidity ratio of the prices showed that at the time of research, prices for most APD were correct in relation to consumers; and high price competition is inherent in 5 drugs of ASA. Within the government program "Available medicines" patients can receive 1 Clopidogrel TN free of charge, for 19 TN $61.9 \%-$ $98.9 \%$ of their costs are reimbursed, and for 3 TN consumers must pay about half of their cost.

Key words: ischemic stroke; antiplatelet drugs; social pharmacy.

ISSN 2312-0967. Pharmaceutical review. 2018. № 3 


\section{Список літератури}

1. Левицька О. Р. Ішемічний інсульт: клініко-фрармацевтичні аспекти: монографрія / О. Р. Левицька, Б. П. Громовик, А. Б. Зіменковський. - Львів : ТзоВ «Ліга-Прес», 2014. -223 c.

2. Сучасні принципи діагностики та лікування хворих із гострим ішемічним інсультом та TIA. Адаптована клінічна настанова, заснована на доказах: наказ МО3 України № 602 від 03.08.2012 р. «Про затвердження та впровадження медико-технологічних документів зі стандартизації медичної допомоги при ішемічному інсульті» [Електронний ресурс]. - 2012. - Режим доступу: http://www.moz.gov.ua/ua/portal/dn_20120803_602.html 3. Агренокс [Електронний ресурс]. - Режим доступу: http://mozdocs.kiev.ua/likiview.php?id=4214

4. Іпатон [Електронний ресурс]. - Режим доступу: http:// mozdocs.kiev.ua/likiview.php?id=38551

5. Прозапровадженнявідшкодуваннявартості лікарських засобів: Постанова КМ України від 09.11.2016 р. № 863 [Електронний ресурс]. - Режим доступу: https://www.apteka.ua/article/393210

6. Про забезпечення доступності лікарських засобів : Постанова КМ України від 17.03.2017 р. №152 [Електронний ресурс]. - Режим доступу: https://www.apteka.ua/article/404701

7. Про внесення змін до деяких постанов Кабінету Міністрів України: Постанова КМ України від 27.12.2017 р. № 1080 [Електронний ресурс]. - Режим доступу: http://zakon5.rada.gov.ua/laws/show/1080-2017$\% \mathrm{DO} \% \mathrm{BF}$

8. Про затвердження реєстру лікарських засобів, вартість яких підлягає відшкодуванню станом на 22

\section{References}

1. Levytska OR, Hromovyk BP, Zimenkovsky AB. Ischemic stroke: clinical and pharmaceutical aspects: a monograph [Ішемічний інсульт: клініко-фрармацевтичні аспекти: монографрія]. Lviv: Ltd "Liha-Press"; 2014. 223 р. Ukrainian.

2. Order of the Ministry of Health of Ukraine "On approval and introduction of medical-and-technological documents for standardization of care in ischemic stroke. Modern principles of diagnosis and treatment of patients with acute ischemic stroke and TIA. Adapted clinical guideline based on evidence» from Aug 03, 2012, №602]. [Electronic resource, Ukrainian]. Available from: http://www.moz.gov.ua/ua/portal/ dn 20120803 602.html [Accessed July 2018]. Ukrainian.

3. Agrenox [Electronic resource, Ukrainian]. Available from: http://mozdocs. kiev.ua/likiview.php?id=4214 [Accessed July 2018]. Ukrainian.

4. Ipaton [Electronic resource, Ukrainian]. Available from: http://mozdocs. kiev.ua/likiview.php?id=38551 [Accessed July 2018]. Ukrainian.

5. Postanova KM Ukrainy vid 09.11.2016 r. №863 [On the introduction of reimbursement of the cost of medicines: Resolution of the Cabinet of Ministers of Ukraine of 09.11.2016 № 863. [Electronic resource, Ukrainian]. Available from: https://www.apteka.ua/article/393210 [Accessed July 2018]. Ukrainian. січня 2018 року: наказ МОЗ України від 22.01.2018 р. № 111 [Електронний ресурс]. - Режим доступу: http:// moz.gov.ua/article/ministry-mandates/nakaz-moz-ukrainivid-05022018--177-pro-vnesennja-zmin-do-reestru-likarskih-zasobiv-vartist-jakih-pidljagae-vidshkoduvannju-stanom-na-22-sichnja-2018-roku

9. Адонкіна В. Ю. Оцінка економічної доступності антитромботичної терапії ішемічного інсульту / В. Ю. Адонкіна, О. Я. Міщенко // Клінічна фрармація. 2013. - Т.17, № 1. - С. 8-11.

10. Міщенко О. Я. Клопідогрель у порівнянні 3 аспірином для вторинної профрілактики ішемічного інсульту і смертності у хворих 3 серцево-судинними захворюваннями: фрармакоекономічний аспект / О. Я. Міщенко, В. Ю. Адонкіна, Ю. К. Терентьєва // Клінічна орармація. - 2014. - Т. 18, № 1. - С. 45-48.

11. Вивчення цінової кон'юнктури вітчизняного ринку антиагрегантів / Є. А. Редькіна, Н. О. Ткаченко, В. В. Гладишев, І. О. Пухальська // Актуальні питання фрармацевтичної і медичної науки та практики. - 2017. T. 10, № 2(24). - C. 207-213.

12. Державний реєстр лікарських засобів України [Електронний ресурс]. - Режим доступу: http://www.drlz. com.ual

13. Громовик Б. П. Менеджмент і маркетинг у підручник / Б. П. Громовик, Г. Д. Гасюк, О. Р. Левицька : за ред. д-ра фрармац. наук, профр. Б. П. Громовика. - К. : Медицина, 2008. - 752 с.

14. Defined daily dose, DDD [Electronic resources]. - Available from: https://www.whocc.no/atc_ddd index $/$ ?code $=\mathrm{B} 01 \mathrm{AC}$

6. On ensuring availability of medicines: Resolution of the Cabinet of Ministers of Ukraine dated 17.03.2017 №152. [Electronic resource, Ukrainian]. Available from: https:// www.apteka.ua/article/404701 [Accessed July 2018]. Ukrainian.

7. On Amendments to certain Resolutions of the Cabinet of Ministers of Ukraine: Resolution of the Cabinet of Ministers of Ukraine dated December 27, 2017 No. 1080] [Electronic resource, Ukrainian. Available from: http://zakon5.rada. gov.ua/laws/show/1080-2017-\%D0\%BF [Accessed July 2018]. Ukrainian.

8. On Approval of the Register of Medicinal Products, the value of which is subject to reimbursement as of January 22, 2018. [Electronic resource, Ukrainian]. Available from: http://moz.gov.ua/article/ministry-mandates/nakazmoz-ukraini-vid-05022018--177-pro-vnesennja-zmin-doreestru-likarskih-zasobiv-vartist-jakih-pidljagae-vidshkoduvannju-stanom-na-22-sichnja-2018-roku [Accessed July 2018]. Ukrainian.

9. Adonkina VYu, Mishchenko OYa. [Evaluation of economic availability of antithrombotic therapy of ischemic stroke]. Klin Farmats. 2013;17(1): 8-11. Ukrainian.

10. Mishchenko OYa, Adonkina VYu, Terentieva YuK. [Clopidogrel versus aspirin for the secondary prevention of ischemic stroke and mortality in patients with cardiovas-

ISSN 2312-0967. Фармацевтичний часопис. 2018. № 3 
cular disease: pharmacoeconomic aspect]. Klin Farmats. 2014;18(1):45-8. Ukrainian.

11. Redkina YeA, Tkachenko NA, Gladyshev VV, Pukhalskaya IA. [The study of price situation on the domestic antiplatelet market]. Aktualni Pytannia Farmats i Med Nauky i Praktyky. 2017;10(2): 207-213. Ukrainian.

12. Derzhavnyi reiestr likarskykh zasobiv Ukrainy [Electronic resource, Ukrainian]. Available from: http://www.drlz. com.ua/ [Accessed July 2018]. Ukrainian.

13. Hromovyk BP, Hasiuk HD, Levytska OR. Management and marketing in pharmacy: a textbook. [Менеджмент i маркетинг у фрармації: підручник] Kyiv: Medicine; 2008. Ukrainian.

14. Defined daily dose, DDD [Electronic resource]. - Available from: https://www.whocc.no/atc_ddd_ index/?code=B01AC [Accessed July 2018].

Отримано 04.06.2018 